\title{
Pengaruh NPF dan Gearing Rasio Terhadap Profitabilitas Perusahaan Multifinance yang Terdaftar di Bursa Efek Indonesia
}

\author{
Maria J. F. Esomar, Meiske Wenno \\ Program Studi Manajemen Fakultas Ekonomi dan Bisnis, Universitas Pattimura, Indonesia \\ Email Korespondensi: dyahesomar@gmail.com
}

\begin{abstract}
ABSTRAK
Pada kuartal III tahun 2019, industri multifinance mengalami perlambatan, dan hanya bertumbuh $3.53 \%$. Perlambatan yang terjadi berdampak bagi perkembangan penyaluran dan pengembalian pembiayaan, pendanaan dan profitabilitas perusahaan multifinance. Kehadiran perusahaan Fintech, terjadinya wabah Covid-19 di akhir tahun 2019 dan perubahan perilaku konsumen mempengaruhi kinerja keuangan perusahaan multifinance. Tujuan Penelitian ini adalah untuk menguji pengaruh Non Performing Financing (NPF) dan gearing rasio yang secara parsial berpengaruh signifikan terhadap profitabilitas pada perusahaan multifinance yang terdaftar di Bursa Efek Indonesia periode 2016-2019. Profitabilitas diukur dengan menggunakan Return on Aset (ROA) Pemilihan sampel dilakukan dengan menggunakan metode purposive sampling sehingga diperoleh 11 sampel perusahaan. Teknik analisis data yang digunakan adalah regresi linear berganda dengan program smart PLS 3.0. Hasil penelitian menunjukkan Non Performing Financing (NPF) berpengaruh negatif siginifikan terhadap ROA dan gearing rasio berpengaruh negatif signifikan terhadap ROA.
\end{abstract}

Kata Kunci : Perusahaan multifinance, Non Performing Financing (NPF), gearing rasio, profitabilitas.

\section{ABSTRACT}

In the third quarter of 2019, the multi-finance industry experiences a slowdown, and only grows by $3.53 \%$. The occurred slowdown has an impact on the development of distribution and return of financing, funding and profitability of multi-finance companies. The presence of Fintech Company, the occurrence of the Covid-19 outbreak at the end of 2019 and changes in consumers' behavior influenced the financial performance of multi-finance companies. The objective of this study is to examine the effect of Non-Performing Financing (NPF) and gearing ratio, which partially has a significant effect towards the profitability in multi-finance companies registered on the Indonesia Stock Exchange for the period 2016-2019. Profitability is measured using the Return on Assets (ROA). The sample selection is conducted by using a purposive sampling method which obtains 11 sample companies. The data analysis technique applied is the multiple linear regression with the smart PLS 3.0 program. The results of the study displays that Non Performing Financing (NPF) has significant negative effect towards ROA and the gearing ratio has significant negative effect towards ROA.

Keyword : Multi-finance company, Non Performing Financing (NPF), ratio gearing, profitability

\section{PENDAHULUAN}

Ekonomi global yang melambat mendorong perusahaan multifinance untuk melakukan ekspansi pasar dan produk agar dapat bertumbuh. Perkembangan industri multifinance pada 
kuartal III tahun 2019 mengalami perlambatan, dan hanya bertumbuh 3.53\%. Perubahan perilaku konsumen khususnya generasi milenial menjadi salah faktor menurunnya pertumbuhan mutifinance. Kehadiran trasnportasi dalam jaringan mempengaruhi perubahan perilaku konsumen. Kemudahan dan efisiensi dari pelayanan transportasi tersebut dibandingkan menggunakan kendaraan pribadi menjadi tantangan industri mutifinance. Fenomena tersebut mendorong konsumen untuk mengurungkan niat membeli kendaraan motor, padahal pembiayaan kendaraan bermotor memberi kontribusi $66.05 \%$ dari total pembiayaan. Kehadiran perusahaan fintech yang masif masuk ke sektor pembiayaan menjadi tantangan bagi perusahaan multifinance. Perusahaan multifinince diharapkan berinovasi mengembangkan teknologi digital untuk aktivitas bisnisnya.

Industri multifinance dalam perkembangannya masih diperhadapkan dengan tantangan perlambatan laju pembiayaan. Lembaga otoritas jasa keuangan sampai agustus 2018 mencatat nilai industri pembiayaan mencapai Rp 431,9 triliun. Sejauh ini, pertumbuhan tersebut masih terpaut cukup jauh dari proyeksi awal yang ditetapkan industri ini yaitu mencapai $8 \%$. Tantangan ini semakin terasa akhir tahun 2018 yaitu menurunnya pendanaan yang didapat perusahaan multifinance. Penyaluran kredit sangat tergantung pada sumber dana, jika sisi pendanaan terganggu maka penyaluran kredit menjadi tidak optimal, dan tantangan pelemahan nilai tukar rupiah membuat perusaahan multifinance cukup sulit untuk mencari pendanaan dari luar negeri.

Perusahaan multifnance turut berkontribusi untuk kemajuan perekonomian Indonesia. Melalui perusahaan multifinance, dapat menciptakan lapangan kerja, menyalurkan pembiayaan ke sektor- sektor produktif, dan pemberdayaan ekonomi daerah melalui beroperasinya kantor - kantor cabang perusahaan multifinance disetiap daerah. Perkembangan perusahaan multifinace dipengaruhi oleh faktor makro dan mkro ekonomi. Faktor makro ekonomi antara lain nilai tukar rupiah, suku bunga dan inflasi. Faktor mikro ekonomi berkaitan dengan kondisi internal perusahaan. Dalam penelitian ini menggunakan fakto mikro yang terjadi dari dalam perusahaan yaitu penyaluran kredit yang bermasalah, pendanaan perusahaan dan profitabilitas perusahaan.

Peningkatan kredit bermasalah dan menurunannya kualitas pendanaan serta profitabulitas industri multifinance akan berdampak bagi perkembangan industri non perbankan di Indonesia dan mempengaruhi kebijakan ekonomi pemerintah. Salah satu kebijakan yang dikeluarkan pemerintah untuk mendorong pertumbuhan sektor multifnance yaitu kelomggaran cicilan nasabah yang mengalami dampak dari terjadinya covid 19. Dari sisi pendanaan, pemerintah telah mengeluarkan berbagai kebijakan paket ekonomi namun perusahaan multifnance belum merasakan dampak dari kebijakan pemerintah yang berupa penurunan suku bunga pembiayaan.

Mewabahnya virus corona di akhir tahun 2019 ikut mempengaruhi perekonomian Indonesia dan mempengaruhi kinerja keuangan perusahaan multifinance. Otoritas Jasa Keuangan (OJK) memprediksi pertumbuhan multifinance di tahun 2020 akan mengalami perlambatan akibat virus covid 19 dan menurunnya pertumbuhan sektor otomotif. Aktivitas bisnis perusahaan multifinance banyak menyalurkan pembiayaan kendaraan bermotor, karena itu pelemahan sector otomotif akan mempengaruhi perusahaah multifinance. Data OJK menunjukkan pendanaan perusahaan multifinance di tahun 2019 turun 2.5\% dibandingkan tahun sebelumnya dan $20 \%$ dari perusahaan pembiayaan belum memenuhi aturan modal minimal Rp100 milyar. Perkembangan kredit bermasalah atau NPF sebesar 2.4\%, namun dari sisi laba megalami kenaikan $12 \%$ dibandingkan tahun lalu. Perusahaan multifinance diharapkan mampu menjaga keseimbangan antara pertumbuhan piutang pembiayaan, kualitas piutang pembiayaan dan pendanaan operasional perusahaan.

Profitabilitas merupakan kemampuan perusahan dalam memperoleh laba (keuntungan) secara optimal dengan mempergunakan sumber-sumber daya dalam bentuk modal yang 
dimiliki oleh perusahan dalam suatu periode usaha tertentu, alat untuk mengukur laba (profitabilitas) adalah margin laba (profitmangin), return on asset (ROA), return on equitty(ROE), return on total asset, bassic earning power, earning per share, dan contribution margin. Alat ukur yang digunakan dalam penelitian ini adalah return on asset (ROA). Rasio ini akan memberikan ukuran yang lebih baik atas profitabilitas perusahan karena menunjukan efektifitas manajemen dalam mengelola kegiatan perusahan untuk memperoleh pendapatan. (Fama \& French, 2006).

Non Performing Financing (NPF) merupakan alat ukur yang dapat digunakan perusahaan multifinance untuk mengukur risiko pembayaran kredit. Semakin tinggi NPF, semakin tinggi risiko pembiayaan yang artinya kredit macet semakin meningkat, sebaliknya jika NPF semakin rendah menunjukkan pengelolaan kualitas kredit yang semakin membaik. Kegiatan perusahaan multifinance dalam bentuk penyediaan dana atau barang kebutuhan konsumen, Kegiatan pembiayaan yang dilakukan mengandung risiko gagal bayar, hal ini menjadi tantangan yang harus bisa dikendalikan agar perusahaan dapat meningkatkan keuntungan dan menjaga keberlanjutan perusahaan.

Gearing rasio merupakan jumlah pinjaman dibandingkan dengan modal sendiri. Berdasarkan ketentuan Menteri Keuangan No.: 222/PMK.010/2008 Gearing Rasio penjaminan usaha produktif maksimlal 10 kali. Rasio Gearing yang rendah berarti perusahaan stabil secara finansial dan memiliki risiko perubahan tingkat suku bunga yang rendah. Di mata investor rasio gearing yang tinggi akan lebih berisiko, dan hal ini akan membuat investor tidak ingin mendanai perusahaan. Investor dan kreditur lebih memilih perusahaan yang memiliki rasio gearing yang rendah. Perusahaan mutifinance dapat menjaga rasio gearing dengan meningkatkan laba. Laba yang meningkat, membuat perusahaan mendapatkan tambahan modal sehingga dapat menurunkan gearing rasio.

Tabel 1. Perkembangan NPF, Gearing Rasio dan ROA Perusahaan Pembiayaan Tahun $2016-2019$

\begin{tabular}{|c|c|c|c|}
\hline Tahun & $\begin{array}{c}\text { Non Performing Financing } \\
\text { (NPF) }\end{array}$ & Gearing Rasio (GR) & ROA \\
\hline $\mathbf{2 0 1 6}$ & $3.26 \%$ & $3.03 x$ & $3.87 \%$ \\
\hline $\mathbf{2 0 1 7}$ & $2.96 \%$ & $2.99 x$ & $4.03 \%$ \\
\hline $\mathbf{2 0 1 8}$ & $2.71 \%$ & $2.99 x$ & $4.36 \%$ \\
\hline $\mathbf{2 0 1 9}$ & $2.40 \%$ & $2.61 x$ & $4.79 \%$ \\
\hline
\end{tabular}

Sumber : Statistik lembaga pembiayaan OJX.go.id

Sampai dengan Desember 2019 terdapat 16 perusahaan yang telah terdaftar di Bursa Efek Indonesia. Proporsi nilai piutang pembiayaan dari perusahaan multifinance yang sudah go public (terbuka) $20.57 \%$, dan piutang pembiayaan yang belum go public (tertutup) sebesar 79.43\%. Tabel 1 menunjukkan rasio kredit bermalasalah atau NPF cenderung menurun dari tahun 2016-2019, artinya kulitas pengelolaan kredit pada perusahaan - perusahaan pembiayaan semakin membaik. Rasio Gearing merupakan jumlah pinjaman dibandingkan modal sendiri. Rasio Gearing tahun 2016 sebesar 3.03 kali menurun menjadi 2.61 kali di tahun 2019. Penurunan gearing rasio disebabkan karena perlambatan industri pembiayaan . Gearing rasio akan meningkat jika adanya penambahan pendanaan. Dari sisi ROA meningkat $3.87 \%$ ditahun 2016 menjadi $4.79 \%$ di tahun 2019, artinya perusahaan mulitifinance/pembiayaan mampu mengelola asetnya untuk memperoleh keuntungan. ROA dapat digunakan sebagai dasar perencanaan keuangan.

Penelitian ini didasarkan oleh perbedaan penelitian terdahulu yang menghasilkan simpulan penelitian yang berbeda. Penelitian Faditya khira menunjukkan NPF tidak 
berpengaruh signifikan terhadap profitablitas.(Ummah \& Suprapto, 2020) sementara penelitian Yusuf (Yusuf \& Surjaatmadja, 2018) dan penelitian Harianto.(Harianto, 2017) NPF berpengaruh signifikan terhadap profitabilitas. Penelitan Sabunwala, 2012 (Directory, Publishing, Opportunities, \& J-gage, 2012), dan penelitian (Senthilmani, 2013) menunjukkan rasio gearing berpengaruh negatif terhadap profitabilitas sementara Penelitian quarniah menunjukkan rasio utang terhadap modal tidak berpengaruh terhadap profitabilita.(Qur'anih \& Isynuwardhana, 2018).

Tujuan penulisan ini adalah untuk mengetahui apakah Non Performing Financing (NPF) dan gearing rasio secara parsial berpengaruh secara signifikan terhadap profitabilitas pada perusahaan multifinance yang terdaftar di Bursa Efek Indonesia periode 2016-2019. Profitabilitas diukur dengan menggunakan Return on Aset (ROA). Perkembangan rasio NPF dan gearing rasio pada sektor multifinance memberi dampak bagi kebijakan ekonomi Indonesia. Kebijakan ekonomi yang dikeluarkan pemerintah untuk meningkatkan profitabilitas perusahaan sektor multifinance antara lain restrukturisasi penagguhan kredit bank dan lembaga pembiayaan/multifiance, namum perlu dianalisis apakah kebijakan ekonomi yang dikeluarkan pemerintah untuk sektor bank dan lembaga pembiayaan dapat meningkatkan profitabilitas dan menurunkan jumlah kredit bermasalah yang disalurkan oleh lembaga pembiayaan atau multifinance.

Kondisi Sub sektor multifinance yang melambat dan dipengaruhi perubahan perilaku konsumen serta dampak wabah covid 19 belum tentu memberikan dampak yang baik bagi perkembangan penyaluran dan pengembalian pembiayaan, pendanaan dan profitabilitas perusahaan multifinance.

\section{MATERI DAN METODE}

\section{Perusahaan Multifinance/Perusahaan Pembiayaan}

Aktivitas perusahaan pembiayaan atau multifinance di Indonesia mulai beroperasional pertama kali oleh pemerintah pada tahun 1974. Perusahaan multifinance merupakan badan usaha yang melakukan aktivitas pembiayaan untuk pengadaan barang dan jasa juga barang konsumen. Perusahaan multifinance tidak melakukan penarikan dana langsung dari masyarakat. Perusahaan pembiayaan meliputi kegiatan sewa guna usaha, anjak piutang, kartu kredit dan pembiaayan konsumen. Dalam perkembangan, aktivitas kegiatan perusahaan multifinance diperluas mencakup pembiayaan investasi, pembiayaan modal kerja, pembiayaan multiguna dan kegiatan usaha pembiayaan lainnya berdasarkan aturan Otoritas Jasa Keuangan (OJK). (OJK, 2014). Dengan aturan baru OJK, perusahaan dapat memperluas bisninya, serta menyalurkan kredit yang merupaka program pemerintah, contohnya Kredit Usaha Rakyat (KUR) untuk memberdayakan usaha mikro, kecil, dan menengah (UMKM). Perusahaan finansial yang adalah lembaga non bank memberikan kemudahan finansial.

\section{Teori Struktur Modal}

Perusahaan dalam melaksanakan aktivitas bisnis memerlukan struktur modal yang optimal. Struktur modal perusahaan adalah komposisi pendanaan dalam menggunakan hutang dan modal sendiri Struktur modal yang optimal akan meningkatkan nilai perusahaan dan profitabilitas, karena itu keputusan pendanaan harus dibuat secara tepat.(Danis, Rettl, \& Whited, 2014) Terdapat beberapa teori dalam struktur modal yaitu teori pendekatan tradisional, teori Modigliani dan Miller, teori trade off dalam struktur modal, teori pecking order, teori asimetri informasi dan signaling dan teori keagenan. Teori struktur modal akan membantu perusahaan dalam membuat keputusan pendanaan sesuai dengan jenis usahanya. Gearing rasio merupakan alat yang dapat digunakan untuk mengukur risiko pendanaan. 
Struktur modal menjadi hal penting bagi perusahaan karena mempunyai dampak langsung terhadap kondisi keuangan perusahaan.

\section{Profitabilitas}

Tujuan suatu perusahaan antara lain memperoleh laba atau keuntungan yang maksimal. Rasio profitabilitas dapat digunakan untuk mengukur tingkat keuntungan suatu perusahaan, digunakan rasio keuntungan atau rasio profitabilitas. Profitabilitas merupakan kemampuan yang dimiliki perusahaan untuk memperoleh laba dan berhubungan dengan penjualan, total aktiva maupun modal sendiri. (Faisal, Samben, \& Pattisahusiwa, 2018). Dengan adanya laba yang diperoleh dapat menjamin keberlangsungan perusahaan. Perusahaan akan berusaha meningkatkan profitabilitasnya agar usaha perusahaan dapat terjamin. Profitabilitas mengukur kemampuan perusahaan menggunakan sumber daya yang dimiliki baik itu penjualan, aktiva dan modal. Profitabilitas tepat digunakan untuk mengukur efektifitas managemen dan mengevaluasi kinerja managemen dalam menjalankan aktivitas bisnis dan produktifitas dalam mengelola aset-aset perusahaan

\section{Pengembangan Hipotesis}

\section{Pengaruh Non Performing Financing (NPF) terhadap profitabilitas}

NPF merupakan alat ukur risiko kegagalan pembiayaan. NPF merupakan perbandingan antara pembiayaan bermasalah dengan total pembiayaan yang diberikan. (Wibowo, Syaichu, \& Manajemen, 2013). Menurut ketentuan Bank Indonesia, NPF maksimal sebesar 5\%.. Semakin tinggi NPF perusahaan mutifinance, maka risiko perusahaan pada pembiayaan bermasalah akan semakin meningkat. NPF merupakan kondisi dimana pengembalian kredit mengalami risiko gagal bayar. Perusahaan multifinance sebaiknya menjaga posisi rasio ini berada dalam angka ideal karena aktivitas pembiayaan merupakan kontribusi terbesar dalam meningkatkan pendapatan perusahaan. Apabila NPF atau pembiayaan bermasalah lebih dari 5\% menunjukkan kinerja keuangan yang kurang sehat dan perusahaan bisa memperoleh kerugian yang akan menurunkan rasio profitabilitas antara lain rasio Return On Aset (ROA). Dengan demikian NPF dapat mempengaruhi profitabiltas, hal ini sejalan dengan penelitian Edhi Wibowo tahun 2013(Wibowo et al., 2013) dan Syawal Harianto (Harianto, 2017)

Hipotesis 1 : NPF berpengaruh negatif terhadap ROA

\section{Pengaruh Gearing Rasio terhadap profitabilitas}

Sumber pendanaan perusahaan terdiri dari modal dari pemegang saham dan utang. Gearing rasio menunjukkan operasional perusahaan yang didanai pinjaman (utang) dibandingkan dengan modal yang dimiliki perusahaan. Rasio ini dapat menjadi ukuran utang yang berguna dan dapat digunakan sebagai signal bagi perusahaan yang mana waktu yang tepat untuk meminjam dan kapan menggunakan modal sendiri.. Rasio gearing maksimal 10 kali. (Ratio, Ratio, Ketentuan, \& Gearing, 2008). Rasio gearing yang tinggi menunjukkan sumber pendanaan perusahaan mayoritas berasal dari pinjaman, dalam bentuk utang jangka pendek maupun jangka panjang. Rasio gearing juga menggambarkan kemampuan jumlah ekuitas yang akan digunnakan untuk membayar utang. (Akhtar, Ali, \& Sadaqat, 2011). Perusahaan dengan gearing yang rendah memilik risiko yang kecil karena dianggap akan lebih mampu melunasi hutang. Perusahaan dengan gearing tinggi berisiko tinggi karena penurunan atau kenaikan suku bunga pinjaman dapat meningkatkan risiko gagal bayar. Dalam penelitian Sabunwala 2012 menemukan gearing rasio berpengaruh negatif terhadap profitabilitas. (Yulianti, 2019).

Hipotesis 2 : Gearing rasio berpengaruh negatif terhadap ROA 


\title{
METODE PENELITIAN
}

Populasi dalam penelitian ini adalah 16 perusahaan Multifinance yang tercatat di Bursa Efek Indonesia periode waktu 2016-2019. Teknik penentuan saampel dalam penelitian ini dengan menggunakan purposive sampling. Adapun kriteria-kriteria dipilihnya anggota populasi menjadi sampel dalam penelitian ini adalah :

1. Perusahaan-perusahaan yang masuk dalam kelompok Perusahaan Multifinance yang terdaftar di Bursa Efek Indonesia periode 2016-2019.

2. Perusahaan yang telah mempublikasi laporan keuangan selama 4 tahun berturutturut mulai dari tahun 2016-2019.

3. Perusahaan yang mendapat keuntungan selama 4 tahun berturut-turut dari tahun 2016-2019.

Berdasarkan pada kriteria pengambilan sampel seperti yang telah disebutkan diatas, maka jumlah sampel dalam penelitian ini sebanyak 11 perusahaan. Sumber data yang dipakai yaitu data sekunder, yaitu data yang diperoleh dari berbagai sumber seperti buku, jurnal dan sebagainya. Data yang digunakan penelitian ini adalah laporan keuangan audit tahun 20162019. Bersumber dari laporan publikasi Bursa Efek Indonesia (BEI) melalui situs resminya dengan alamat http://www.idx.co.id. Metode analisis data yang digunakan dalam penelitian ini menggunakan analisis regresi berganda (multiple regression analysis) dengan program SmartPLS versi 3.0. Metode tersebut digunakan untuk meramalkan pengaruh dari suatu variable terikat (laba perusahaan) berdasarkan variable bebas (NPF dan Gearing rasio).

\section{R Square}

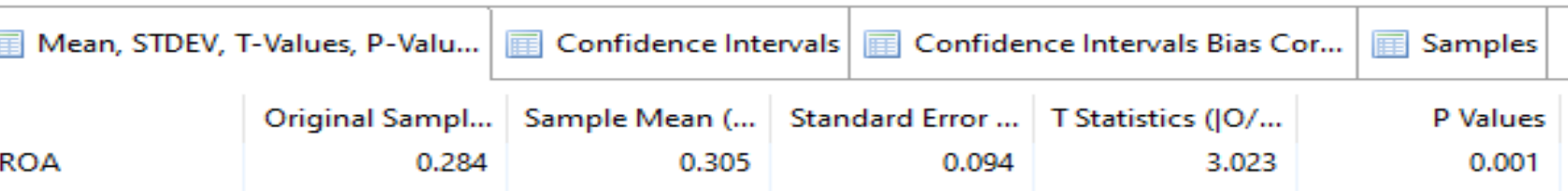

\author{
Gambar 1 R Square \\ Sumber: Hasil Olahan Data PLS 3.0 (2020)
}

Berdasarkan hasil output SmartPLS 3 di atas, dapat dilihat bahwa nilai R-Square yang dihasilkan sebesar 0,284 yang artinya bahwa pengaruh variable Rasio NPF dan Rasio Gearing terhadap ROA adalah sebesar $28,4 \%$ dan sisanya $71,6 \%$ dipengaruhi oleh variabel lain di luar model penelitian ini.

\section{Path Coefficients}

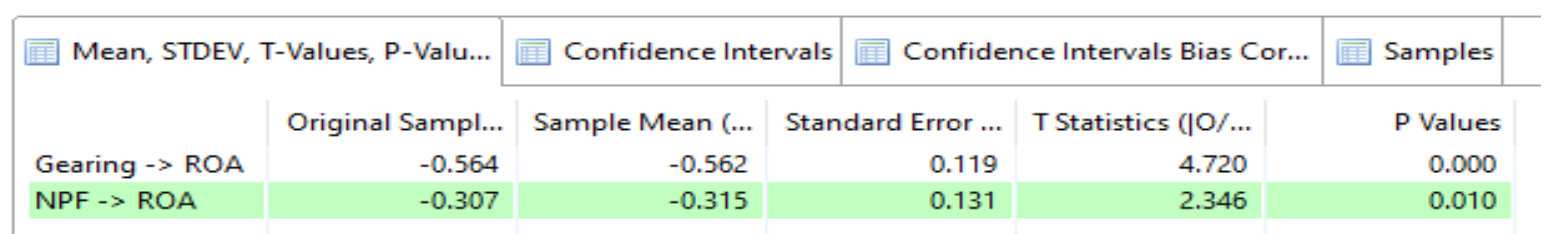

Gambar 2 : Hasil Uji Regresi Berganda

Sumber: Hasil Olahan Data PLS 3.0 (2020) 


\section{Hasil Pengujian Hipotesis}

Hipotesis 1 : NPF berpengaruh negatif terhadap ROA

Hioptesis 2 : Gearing rasio berpengaruh negatif terhadap ROA

Berdasarkan hasil output SmartPLS 3 di atas, dapat dilihat bahwa:

1. Variable Rasio NPF berpengaruh negatif terhadap ROA dengan T-statistics sebesar 4,720 $>$ 1,96. Dengan demikian H1 diterima.

2. Variable Rasio Gearing berpengaruh negatif terhadap ROA dengan T-statistics sebesar 2,346 > 1,96. Dengan demikian H2 diterima.

\section{HASIL DAN PEMBAHASAN}

\section{Pengaruh NPF terhadap Profitabilitas (ROA)}

Hipotesis pertama dari penelitian ini menyebutkan NPF berpengaruh negatif signifikan terhadap profitabilitas. Berdasarkan hasiil uji statistik dengan T-statistics sebesar 4,720 > 1,96, dengan demikian terdapat pengaruh negatif signifikan terhadap profitabilitas (ROA). Semakin kecil rasio NPF, keuntungan dapat meningkat. NPF yang rendah menunjukkan perusahaan mampu mengelola piutang pembiayaan dengan baik. Dari hasil perhitungan, NPF perusahaan multifinance yang terdaftar di Bursa Efek Indonesia masih tergolong rendah karena berada dibawah 5\%. Profitabilitas dapat meningkat jika NPF berada dibawah 5\%. Pembiayaan bermasalah/NPF yang tinggi akan mempengaruhi perolehan pendapatan perusahaan dan mengurangi laba. NPF mencerminkan risiko yang dihadapi perusahaan pembiayaan.

Untuk menjaga rasio NPF dibawah 5\%, perusahaan multifinance sebaiknya menjaga kualitas pembiayaan dan melakukan analisa yang tepat dalam menyalurkan pembiayaan. Rasio NPF yang merupakan proporsi kualitas aset piutang pembiayaan kategori macet dan diragukan terhadap keseluruhan piutang pembiayaan. Kualitas kredit terdiri dari lima kategori, yakni lancar, dalam perhatian khusus, kurang lancar, diragukan, dan macet. Kenaikan NPF dapat terjadi bukan hanya karena jumlah pembiayaan bermasalah yang meningkat tetapi juga karena menurunnya pembiayaan yang disalurkan kepada konsumen pada masa wabah pandemi Covid-19.

Rasio Kredit bermasalah untuk sektor multifinance masih dapat dikendalikan. Kebijakan pemerintah yang dikeluarkan OJK (Otoritas Jasa Keuangan ) berupa restrukturisasi kredit berdampak pada terkendalinya rasio kredit bermasalah yang tidak melebih 5\%. Kebijakan restrukturisasi atau restrukturisasi kredit yang dikeluarkan pemerintah mampu menjaga stabilitas keuangan dan menjaga risiko kredit bermaaslah perusahaan - perusahaan multifinance.

Hasil penelitian ini sejalan dengan hasil penelitian(Harianto, 2017) dan penelitain (Ubaidillah, 2017) yang menyatakan bahwa NPF berpengaruh negatif signifikan terhadap profitabilitas, hal ini menunjukkan bahwa semakin kecil rasio NPF, semakin mampu meningkatkan profitabilitas pada perusahaan multifinance yang disebabkan karena piutang pembiayaan yang dimiliki perusahaan dapat dikelola secara optimal pada setiap periode, sehingga pendapatan yang diterima perusahaan mampu meningkatkan profitabilitasnya.

\section{Pengaruh Gearing Rasio terhadap Profitabilitas (ROA)}

Hipotesis kedua dari penelitian ini menyebutkan Rasio Gearing berpengaruh negatif terhadap profitabilitas. Berdasarkan hasiil uji statistik ROA dengan T-statistics sebesar 2,346 > 1,96. dengan demikian $\mathrm{H} 2$ diterima. Hal ini menunjukkan terdapat pengaruh negatif signifikan antara rasio gearing terhadap profitabilitas (ROA). Gearing rasio menunjukkan jumlah pinjaman dibandingkan dengan modal sendiri. Gearing rasio perusahaan multifinance menurut Peraturan Menteri Keuangan (PMK) Nomor 84/2006 tentang Perusahaan Pembiayaan, menjelaskan 
gearing ratio maksimal 10 kali. Sementara itu OJK menyarankan sebaiknya gearing rasio perusahaan multifinance kurang dari $5 \mathrm{kali}$, hal ini untuk mengurangi risiko gagal bayar atas pinjaman yang dilakukan perusahaan. Perusahaan multifinance menjaga gearing rasio dalam posisi ideal dengan cara meningkatkan laba. Dengan meningkatnya laba, maka perusahaan dapat meningkatkan modal sendiri sehingga bisa menurunkan gearing rasio. Perusahaan multifinance dalam membuat keputusan terhadap jumlah modal perusahaan yang berasal dari pinjaman luar harus dapat mempertimbangkan antara profitabilitas dan risiko. Oleh karena itu jika sebuah perusahaan dapat mengelola utang dan modal dengan lebih efisien maka perusahaan tidak kesulitan dalam hal pendanaan dan pembiayaan dapat terus disalurkan kepada konsumen sehingga akan meningkatkan profitabilitas.

Kebijakan yang dikeluarkan Bank Indonesia berdampak positif terhadap perusahaan multifinance, khususnya dalam hal pendanaan atau permodalan. Penurunan suku bunga BI rate membantu perusahaan pembiayaan untuk mendapatkan sumber pendanaan melalui bank dengan suku bunga pinjaman yang lebih rendah. Dengan kebijakan yang dikeluarkan pemerintah ini memberi dampak dengan masih terjaganya gearing rasio perusahaan multifinance dalam posisi ideal. Permodalan yang tetap terjaga, membuat perusahaan multifinance dapat terus bergerak mengembangkan bisnisnya dan pada akhirnya dapat memberikan konstribusi positif bagi pertumbuhan ekonomi Indonesia.

Penelitian ini sesuai dengan hasil penelitian Sabunwala 2012 dan penelitian Shah Khan (Shah Khan, Ejaz, \& Aslam, 2014) ) yang menyatakan bahwa gearing rasio berpengaruh negatif signifikan terhadap profitabilitas,.

Meningkatnya NPL merupakan dampak dari krisi keuangan global. Persaingan bisnis antar perusahaan semakin ketat. Perusahaan multifinance berusaha memperkuat struktur modalnya. Pembatasan pemberian kredit akan memberikan pengaruh negatif terhadap perekonomian Indonesia. Perusahaan mengalami kesulitaan dalam meningkatkan pendapatan dan mengalami penurunan dalam kemampuan bayar pinjaman. Peningkatan kredit macet dan terbatasnya modal akan mempengaruhi sektor rill karena terbatasnya aliran kas masuk perusahaan. Aktivitas bisnis perusahaan akan terganggu dan mempengaruhi perkembangan ekonomi dan meningkatkatnya risiko krisis ekonomi. Menjaga keberlangsungan perusahaan sekaligus menjaga sektor bisnis yang menjadi penentu tidak terjadinya krisis ekonomi.

\section{KESIMPULAN}

Non Performing Financing (NPF) dan Gearing rasio perusahaan multifinance yang terdaftar di Bursa Efek Indonesia (BEI) selama periode penelitian masih berada dalam angka ideal. Untuk NPF kurang dari 5\% dan rasio Gearing kurang dari 10 kali. Pada periode penelitian Perusahaan multifinance yang terdaftar di BEI mampu menjaga NPL dan gearing rasio dan memperoleh laba walaupun indutri multifinance mengalami perlambatan dan tantangan wabah Covid 19. Kinerja yang baik ini karena perusahaan multifnance berhati-hati dalam menyalurkan pembiayaan dan efektif dalam memanfaatkan aktivitas pendanaan untuk menghasilkan laba. Berdasarkan hasil output SmartPLS 3 di atas, dapat dilihat bahwa Non Performing Financing (NPF) berpengaruh negatif terhadap profitabilitas dengan kata lain semakin kecil NPF maka proftibailitas dapat meningkatt. Rasio Gearing berpengaruh negatif terhadap rofitabilitas, artinya semakin kecil gearing rasio dapat meningkatkan laba karena komposisi pendanaan lebih banyak menggunakan modal sendiri daripada hutang. Beban utang perusahaan yang terlalu besar akan mengurangi laba.

Kebijakan yang dikeluarkan pemerintah baik dari sisi penyaluran kredit dan pendanaan memberikan dampak positif bagi pertumbuhan industri multifinace. Kebijakan restrukturisasi kredit membantu perusahaan multifinance mengatasi kredit bermasalah (NPF) dan melalui 
penurunan SBI perusahaan multifinance dapat memperoleh akses permodalan dari bank dengan suku bunga yang lebih rendah.

Dari hasil penelitian ini, peneliti menyarankan Perusahaan multifinance konsisten mengendalian pembiayaan bermasalah sehingga perusahaan tetap memperoleh profitabilitas . Kualitas pembiayaan yang buruk, akan meningkatkan risiko. Perusahaan diharapkan membuat keputusan pendanaan yang tepat. Gearing rasio yang hitung dibawah 10 kali, kontiribusi utang dan modal sendiri digunakan secara efektif untuk aktivitas bisnis perusahaan yang dapat meningkatkan pendapatan dan profitabilitas perusahaan.

Bagi investor, diharapkan hasil penelitian ini dapat memberikan manfaat dalam melakukan investasi pada industri multifinance. Dimana sebaiknya investor memperhatikan implikasi dari Non Performing Financing (NPF) dan Gearing rasio pada perusahaan pembiayaan. Selain itu juga penelitian ini memberikan informasi kepada investor dalam mengambil keputusan berdasarkan informasi tingkat profitabilitas dari perusahaan multifinance yang tercatat pada Bursa Efek Indonesia (BEI).

Bagi Pemerintah, diharapkan dapat terus mendorong pertumbuhan pelaku industri jasa keuangan melalui kebijakan keuangan yang berdampak positif bagi profitabilitas perusahaan multifnance, penyaluran pembiayaan sektor produktif ke konsumen dan penyediaan lapangan kerja sehingga ekonomi tetap terus bergerak dan bertumbuh

\section{DAFTAR PUSTAKA}

Akhtar, M. F., Ali, K., \& Sadaqat, S. (2011). Factors influencing the profitability of Islamic banks of Pakistan. International Research Journal of Finance and Economics.

Danis, A., Rettl, D. A., \& Whited, T. M. (2014). Refinancing, profitability, and capital structure. Journal of Financial Economics. https://doi.org/10.1016/j.jfineco.2014.07.010

Directory, P., Publishing, E., Opportunities, P., \& J-gage, O. (2012). www.ijrcm.org.in. 3(1041).

Faisal, A., Samben, R., \& Pattisahusiwa, S. (2018). Analisis kinerja keuangan. KINERJA. https://doi.org/10.29264/jkin.v14i1.2444

Fama, E. F., \& French, K. R. (2006). Profitability, investment and average returns. Journal of Financial Economics. https://doi.org/10.1016/j.jfineco.2005.09.009

Harianto, S. (2017). Rasio Keuangan dan Pengaruhnya Terhadap Profitabilitas Pada Bank Pembiayaan Rakyat Syariah. ESENSI. https://doi.org/10.15408/ess.v7i1.4076

OJK. (2014). POJK No 29/POJK.05/2014.

Qur'aniah, M., \& Isynuwardhana, D. (2018). Pengaruh Rasio Keuangan Terhadap Pertumbuhan Laba Pada Perusahaan MOdal Ventura Syariah ( Study Kasus Pada PT. Investama Ventura Syariah Periode 2009-2016). E-Proceeding of Management.

Ratio, G., Ratio, K. G., Ketentuan, P., \& Gearing, T. (2008). No Title. 3(3), 4-5.

Senthilmani, T. (2013). Impact of Working Capital Management on Profitability in UK Manufacturing Industry. SSRN Electronic Journal. https://doi.org/10.2139/ssrn.2345804

Shah Khan, M. M., Ejaz, F., \& Aslam, E. (2014). Determinants of Profitability of Islamic Banking Industry: An Evidence from Pakistan. Business \& Economic Review. https://doi.org/10.22547/ber/6.2.2

Sufiana, N., \& Purnawati, N. K. (2013). Perputaran Persediaan Terhadap Profitabilitas. Fakultas Ekonomi Unud.

Ubaidillah, U. (2017). ANALISIS FAKTOR-FAKTOR YANG MEMPENGARUHI PROFITABILITAS BANK SYARIAH DI INDONESIA. El-Jizya : Jurnal Ekonomi Islam. https://doi.org/10.24090/ej.v4i1.2016.pp1510188 
Ummah, F. K., \& Suprapto, E. (2020). FAKTOR-FAKTOR YANG MEMPENGARUHI PROFITABILITAS PADA BANK MUAMALAT INDONESIA. JURNAL EKONOMI DAN PERBANKAN SYARIAH. https://doi.org/10.46899/jeps.v3i2.159

Wibowo, E. S., Syaichu, M., \& Manajemen, J. (2013). ANALISIS PENGARUH SUKU BUNGA, INFLASI, CAR, BOPO, NPF TERHADAP PROFITABILITAS BANK SYARIAH. DIPONEGORO JOURNAL OF MANAGEMENT.

Yulianti, N. W. (2019). Kinerja Perusahaan Pembiayaan Syariah Di Indonesia Sebelum Dan Sesudah Diberlakukannya Surat Edaran OJK No.48 Tahun 2016 Tentang Besaran Uang Muka Pembiayaan Kendaraan Bemotor Syariah. Jesya (Jurnal Ekonomi \& Ekonomi Syariah). https://doi.org/10.36778/jesya.v2i2.75

Yusuf, M., \& Surjaatmadja, S. (2018). International Journal of Economics and Financial Issues Analysis of Financial Performance on Profitability with Non Performance Financing as Variable Moderation (Study at Sharia Commercial Bank in Indonesia Period 2012-2016). International Journal of Economics and Financial Issues. 